Int. J. Electrochem. Sci., 11 (2016) $4688-4700$

\title{
Mechanical, Microstructural and Tribo-Electrochemistry Characterization in Aqueous Media of Coatings Vanadium / Vanadium Nitride Used as Functional Coating for Implants
}

\author{
W. Aperador ${ }^{*}$, J. Duque, E. Delgado \\ School of Engineering, Universidad Militar Nueva Granada, Bogotá-Colombia \\ *E-mail: g.ing.materiales@gmail.com
}

doi: $10.20964 / 2016.06 .58$

Received: 9 March 2016 / Accepted: 6 April 2016 / Published: 4 May 2016

The study presents tribo-electrochemistry properties of multilayers of Vanadium / vanadium nitride [V $/ \mathrm{VN}] \mathrm{n}(\mathrm{n}=1$, 20, 50 and 100) deposited on surgical grade steel 316LVM through the Physical Vapor Deposition processes (PVD) using Magnetron Sputtering Technology. Nanoindentation tests were performed to determine the hardness of the coatings corrosion tests and assays tribocorrosion (synergy between corrosion and wear), which were carried out with equipment potentiostatic type adapted to a pin on disk tribometer also performed which was adapted to an electrochemical cell with three electrodes: A silver/silver chloride reference electrode $(\mathrm{Ag} / \mathrm{AgCl})$, a counter electrode of platinum and a working electrode immersed in a solution of ringers lactate at a temperature of $37^{\circ} \mathrm{C}$. The evaluation of the tribo-corrosion testing was performed using the electrochemical technique potentiodynamic curve to calculate the value of polarization resistance Tafel polarization curves to determine the corrosion rate in the coatings. The characterization of microstructural and morphological subjected to fretting corrosion coatings it was performed using the technique of atomic force microscopy (AFM).

Keywords: Magnetron Sputtering, corrosion, Vanadium / vanadium nitride, tribo-corrosion, wear. atomic force microscopy, nanoindentation

\section{$\underline{\text { FULL TEXT }}$}

(C) 2016 The Authors. Published by ESG (www.electrochemsci.org). This article is an open access article distributed under the terms and conditions of the Creative Commons Attribution license (http://creativecommons.org/licenses/by/4.0/). 